\title{
Geochemical properties of the Late Pleistocene loess-soil sequence in Dankowice (Niemcza-Strzelin Hills)
}

\author{
Jerzy Raczyk, Zdzisław Jary, Bartosz Korabiewski \\ Institute of Geography and Regional Development, University of Wroctaw, Poland; jerzy.raczyk@uni.wroc.pl
}

\begin{abstract}
Loess-soil sequences provide one of the most continuous and detailed records of the climate changes on land areas in the Quaternary. The Late Pleistocene loess section in Dankowice (Niemcza-Strzelin Hills) is one of the best recognized in SW Poland. For the investigation of the chemical composition of loess-soil sequence in Dankowice, 31 loess samples were tested. Ten main oxides were determined $\left(\mathrm{SiO}_{2}, \mathrm{Al}_{2} \mathrm{O}_{3}, \mathrm{Fe}_{2} \mathrm{O}_{3}, \mathrm{MnO}_{2} \mathrm{MgO}\right.$, $\mathrm{CaO}, \mathrm{Na}_{2} \mathrm{O}, \mathrm{K}_{2} \mathrm{O}, \mathrm{TiO}_{2}$ and $\mathrm{P}_{2} \mathrm{O}_{5}$ ) using certified reference materials to obtain good credibility of the analysis. The chemical composition of loess from Dankowice is similar to the results presented in the world loess literature. The characteristic feature is extremely high concentration of the silica. The chemical composition of loess in Dankowice is differentiated within the vertical sequence and confirm previous division of litho-pedostratigraphic units. Therefore, the chemostratigraphic method can be successfully used as a one of lithostratigraphic methods. Decreasing values of the chemical weathering indices to the top of the section may indicate that the source areas of loess silt have provided material over time, less and less transformed by prolonged and intense chemical weathering processes.
\end{abstract}

Key words: loess-soil sequence, chemical composition, Late Pleistocene, SW Poland

\section{Introduction}

The unceasing attention dedicated to the loess sediments in the worldwide geological literature stems from the fact that the loess-soil sequences provide one of the most continuous and detailed records of the climate changes on land areas in the Quaternary (e.g. Kukla 1970, 1987, Dodonov 2007, Porter 2007, Roberts et al. 2007, Rousseau et al. 2007, Zarate 2007). The environmental and climatic features of the loess deposition as well as the soil development conditions can be reconstructed on the basis of a variety of proxy data. For this purposes, fossil soils, grainsize indices, magnetic properties, malacological, palynological and many others sources of data are commonly used. These data in combination with the methods of absolute dating (e.g. TL, OSL, ${ }^{14} \mathrm{C}$ ) enable a reconstruction of climate and environment and allow to define this in the geological time (e.g. Pye, Sherwin 1999, Muhs, Bettis III 2003, Muhs 2007, 2013).

The search for a new proxy data are one of the major challenges for loess researchers. Studies based on the chemical composition of loess are, nowadays, more frequently published in the geological literature (e.g. Taylor et al. 1983, Pye, Johnson 1988, Gallet et al. 1996, 1998,
Muhs, Bettis III 2000, Jahn et al. 2001, Muhs et al. 2001a, b, 2003, 2008, Sun 2002a, b, Yang et al. 2004, 2006, Buggle et al. 2008, 2011, Ujvari et al. 2008, Ahmad, Chandra 2013). The chemical composition of loess is closely associated with the mineralogical composition of dust

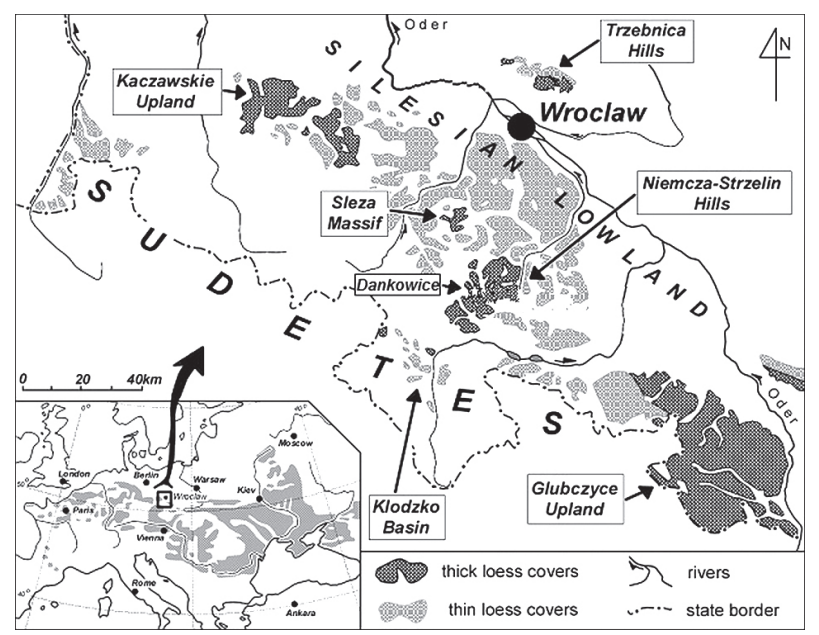

Fig. 1. Location of the Dankowice loess section on the background of the loess distribution in SW Poland (after Jary, 2010 - modified) 
sources, the process of dust transportation from source areas to the places of loess accumulation and also with the conditions of post-depositional processes of weathering and soil genesis. Thus chemical composition of loess can be used as a subsequent lithostratigraphic criterion to verify the stratigraphic subdivisions (Ahmad, Chandra 2013). Unfortunately, geochemical analyses, in current Polish loess literature, are used in a very reduced scope (e.g. Maruszczak 1976, Dwucet, Śnieszko 1996, Dwucet 1999, Łącka et al. 2007). This paper presents an attempt to apply the results of geochemical analyses of loess-soil sequence in Dankowice (Niemcza-Strzelin Hills) to verify the previous lithostratigraphic subdivisions.

Silty covers of the south-western Poland (Fig. 1) are a part of the northern European loess belt (e.g. Różycki 1986, Haase et al. 2007). Loess and loess-derived deposits occur here as a number of isolated, usually thin patches (2-5 m, max. 10 meters; Jary et al. 2002).

Niemcza-Strzelin Hills are one of the best recognized loess areas in SW Poland, although, in the 90's of the last century, the unjustified opinion, that this loess area were stratigraphically undifferentiated, dominated (e.g. Jersak 1973, 1985, 1991). The study of Late Pleistocene loess in Niemcza-Strzelin Hills accelerated at the beginning of this century, when several new loess-soil sequences were exposed and presented for the further verification during the conference field sessions (Jary et al. 2002, Jary 2007, 2010).

\section{The last interglacial-glacial cycle in Dankowice loess-soil sequence}

Loess section in Dankowice $\left(\lambda=17^{\circ} 00^{\prime} 30^{\prime \prime} \mathrm{E}, \varphi=\right.$ $50^{\circ} 43^{\prime} 15^{\prime \prime} \mathrm{N}, 195 \mathrm{~m}$ a.s.1.) composes of interfluve and slope loess facies. It is located on the western periphery of the village, along the road between Dankowice and Stachów. The hilly loess upland in that place is dissected by 5 -meter high road gully.

Loess covers around Dankowice were described by several authors (e.g. Wójcik 1968, Raczkowski 1960, 1969, 1976, Anzel 1974, Ciszek 1997 and others). On the Detailed Geological Map of the Sudeten in scale 1:25000 (Wójcik 1963) the occurrence of loess-like silty clays and loamy loess on this area is marked.

The loess site in Dankowice has been prepared for detailed studies in August and September 2001. In order to fully recognize the loess-soil sequence, at the base of a 3-meter wall the deepening pit was made, reaching the floor of loess. In September 2001, loess section in Dankowice was presented to the participants of XI Polish-Ukrainian Seminar "Stratigraphic correlation of loess and glacial deposits in Poland and Ukraine" for the first time ever (Ciszek et al. 2001). In the year 2004, the loess site in Dankowice was presented to the participants of IV Loess Seminar "Climate changes recorded in the loess successions" (Jary et al. 2004a). For safety reasons, more than 9-meter loess-soil sequence in Dankowice was ex-

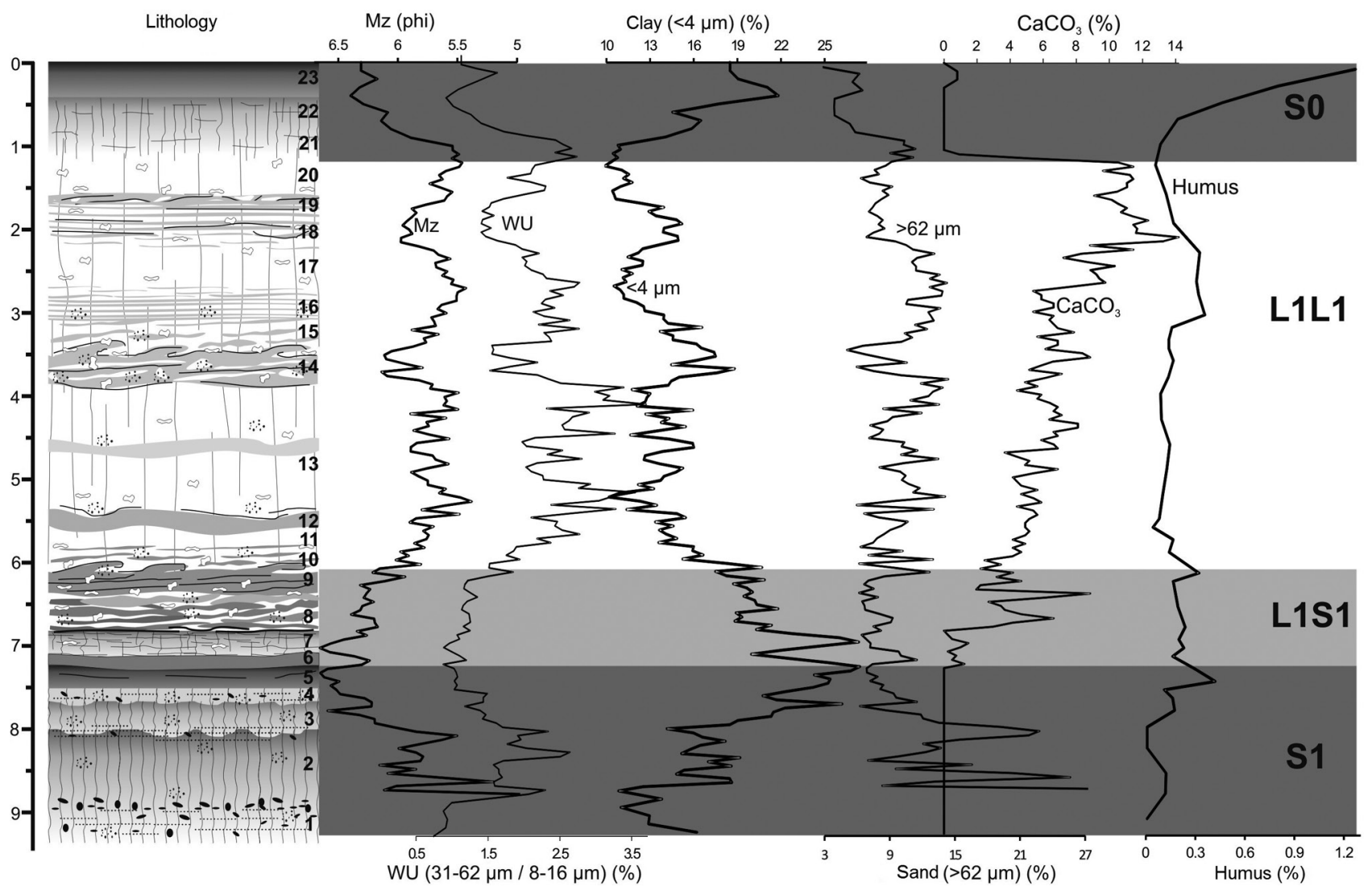

Fig. 2. Lithology and selected lithological indices of the litho-pedostratigraphic units of the Dankowice loess-soil sequence 
cluded from further study and partially buried in subsequent years.

Loess section research results in Dankowice were published many times, mainly in the form of short descriptions and summaries in conference guide books (Ciszek et al. 2001, Jary et al. 2002, 2004a, b, Chlebowski et al. 2004, Fedorowicz et al. 2004, Fedorowicz 2005, 2006, Jary 2007, 2010).

During the fieldwork conducted in Dankowice in autumn 2003, the following litho-pedostratigraphic sequence was described (Fig. 2):

23. 0.00-0.45 Brownish-dark grey, silty horizon. The superimposed A horizon of contemporary soil. $\mathrm{HCl}-$. The gradually downwards transition.

22. 0.45-0.70 Brown, silty horizon, shining gradually downwards. B horizon of contemporary soil. $\mathrm{HCl}-$. The gradual transition.

21. 0.70-1.10 Dark yellow silty, structureless horizon, with small carbonate concretions. $\mathrm{HCl}-$. B/C transitional horizon of brown soil. The gradual, slightly visible transition.

20. 1.10-1.60 Light yellow, massive loess, with single carbonate concretions and forms of secondary carbonate precipitates along the cracks planes. $\mathrm{HCl}+$. The gradual transition.

19. 1.60-1.80 Weak gley level with iron precipitates in the form of streaks, laminaes and nodules. In some places fairly clear signs of deformation. $\mathrm{HCl}+$. The gradual transition.

17. 2.25-2.70 Light yellow, massive loess with weak gleying traces and irregularly distributed carbonate concretions. $\mathrm{HCl}+$. The gradual, indistinct transition.

16. 2.70-3.10 Light yellow streaky and laminated loess. Visible increase of iron at the base. There are small $\mathrm{Fe}$ and $\mathrm{Mn}$ concretions and spots of gley. The sediment shows signs of gelifluctional movement (gentle deflection, waving and folds). $\mathrm{HCl}+$. The fairly clear transition.

15.3.10-3.45 Yellow-gray streaky loess with marks of gley processes. Few of $\mathrm{Fe}$ and $\mathrm{Mn}$ concretions and nodules of $\mathrm{CaCO}_{3}$, especially frequent at the base of layer. The level deformed by cryohydrostatic processes in places. The discontinuous and deformed ferruginous laminaes are indicated. $\mathrm{HCl}+$. The fairly clear transition.

14.3.45-3.80 Grey silt. Occasionally large carbonate concretions randomly distributed throughout the layer and small ferruginous and manganese concretions appear. Spots and streaks of $\mathrm{Fe}^{+3} . \mathrm{HCl}+$ are also locally visible The level of tundra-gley soil. The fairly distinct deformed transition.

13. 3.80-5.40 Light yellow massive less. There are small carbonate concretions and single ferruginous nodules in the entire layer. At depth of 4.2-4.6 m horizontally stretched, lenticular, dark-beige non-concretion forms ferruginous precipitates can be observed. $\mathrm{HCl}+$. The not very clear transition by weakly distinctive streaked with ferruginous spots of gley is marked.
12.5.40-5.55 Grayish loess. Level of weak gley with fine streaks of trivalent iron precipitates imposed. $\mathrm{HCl}+$. The blurred transition.

11. 5.55-5.80 Yellow massive loess with small carbonate and ferruginous concretions, and beige, horizontal structures non-concretion forms of trivalent iron precipitates at the base. $\mathrm{HCl}+$. The blurred transition.

10.5.80-6.15 Beige streaked loess, redeposited by the gelifluction processes. Numerous deflections and folds marked by $\mathrm{Fe}^{+3}$ precipitates. Visible spots of gley and smudges of humic material. There are several carbonate concretions and pseudomycelias. $\mathrm{HCl}+$. The fairly clear transition.

9. 6.15-6.50 Greyish level with visible marks of gley. The top of layer deformed by gelifluction processes. The secondary ferruginous lamination is visible. There are visible fine carbonate concretions, numerous at the base. There are also a few nodules of Fe and $\mathrm{Mn} . \mathrm{HCl}+$. The clear transition.

8. 6.50-6.85 Brown-beige silt. In the floor clear ferruginous laminaes, and in the whole layer the small concretions occur, pseudomycelia and other form of carbonate precipitates. Visible small concretions of Fe and $\mathrm{Mn} . \mathrm{HCl}+$. The clear transition.

7. 6.85-7.10 Dark-brown, structureless sediments. Gently streaked in the top, with single, small carbonate concretions. $\mathrm{HCl} \pm$. The clear transition.

6. 7.10-7.20 Steel-bluish strongly gleyed loess. In the floor enriched with trivalent iron compounds (streaks and laminaes, single ferruginous concretions). $\mathrm{HCl}-$. The clear transition.

5. 7.20-7.45 Brown-gray level of silt with gley traces. Locally marked by a secondary ferruginous lamination. On the bottom there are visible ferruginous streaks and lenses of humic material highlighted by darker color. $\mathrm{HCl}-$. The accumulation level of the fossil soil. The fairly clear transition.

4. 7.45-7.60 Buff-yellow silt in places enriched in highly weathered coarse fractions. A large number of small ferruginous-manganese nodules. In the floor marked by a secondary ferruginous lamination. $\mathrm{HCl}-$. Eluvial level of fossil soil. The clearly transition marked by the color of the sediment.

3. 7.60-8.10 Reddish-beige, silty-sandy level. In the top part there are narrow, $(2-5 \mathrm{~cm})$, bent gelifluction structure, filled with silty gray-bluish material (gley). A small amount of ferruginous-manganese nodules. Visible spots of gley. $\mathrm{HCl}-$. The upper part of the illuvial horizon, gleyed. The fairly clear transition.

2. 8.10-8.90 Brown-beige, rust coloured level with lots of highly weathered fine granules inside the siltysandy matrix. The horizon has clear signs of illuviation similar to the overlying layer. $\mathrm{HCl}-$. The middle part of the illuviation level. The fairly clearly transition, expressed in the lithology of deposit.

1. 8.90-9.30 Sandy-loam, brown-gray-rust color with gley spots. Single granules and small concretions of $\mathrm{Fe}$ and $\mathrm{Mn}$, also visible traces of illuviation processes. 
$\mathrm{HCl}-$. The lower part of the illuviation level. The floor is not reached.

To avoid confusion on the usage of naming the Late Pleistocene stratigraphic units according Jersak (1973) and Maruszczak (1991) and the problems with the correlation of these schemes, the litho-pedostratigraphic units proposed originally for the Loess Plateau in China by Kukla and An (1989) was applied. This scheme was modified by Marković and co-authors (2008), and recently has been used for Polish loess by Jary and Ciszek (2013). The correlation with marine oxygen isotope stages (MOIS; Martinson et al. 1987) also has been made.

The loess-soil units of Dankowice profile during the fieldwork were distinguished, and then verified using the results of laboratory tests. Samples were taken from the vertical sequence in the interval of $5 \mathrm{~cm}$. The investigated section is shown on schematic drawing (Fig. 2). The lithology and selected grain-size characteristics are presented: mean diameters $\mathrm{Mz}$ (phi), the coefficient WU expressing the ratio of coarse silt $(31-62 \mu \mathrm{m})$ to fine silt $(8-16 \mu \mathrm{m})$, the content of the clay fraction $(<4 \mu \mathrm{m})$ and content of the sand fraction $(>62 \mu \mathrm{m})$. The $\mathrm{CaCO}_{3}$ and humus contents also is shown. Grain size distribution on a laser diffractometer Mastersizer 2000 was determined. Carbonates were analyzed by Scheibler method and the organic substance by Tiurin method.

The Late Pleistocene (last $130 \mathrm{ka}$ ) in the loess-soil sequence in Dankowice is represented by four litho-pedostratigraphic units: three soil units (S0, L1S1, S1) and one loess unit (L1L1).

The oldest unit is a polygenetic pedocomplex $\mathrm{S} 1$ (No. 1-5, Fig. 2), which probably evolved during the last interglacial (Eemian $=$ MOIS 5e) and in the early part of the last glacial period (MOIS 5a-5d). The most characteristic horizon of S1 pedocomplex is a thick, tripartite illuvial (Bt) horizon developed on silty-sandy substrate. The content of sand fractions increases towards the base of the section. Above illuvial horizon the eluvial Eetg and accumulation A horizons have developed. The clear visible signs of gleying and periglacial processes in these horizons can be observed. Like in many others loess profiles in south-western Poland, the fossil soils set S1 shows a multistage, complicated history of the development with 2-3 strong stages of forest -type pedogenesis (Jary 2007, 2010, Jary, Ciszek 2013).

There are no loess unit L1L2 in Dankowice as an individual lithostratigraphic unit - it has been degraded or altered by soil-weathering processes associated with the development of pedocomplex L1S1.

The remains of L1L2 loess were transformed during the development of interpleniglacial set of tundra-gley soils L1S1 (No. 7-9; MOIS 3), This pedocomplex consists of well-developed accumulation (A) horizon on the top and cambic $(\mathrm{Bw})$ horizon in the lower part. The upper parts of the tundra-gley soil in the Dankowice section have been deformed by frost heave processes and gelifluction (layer 10).
There is a thick loess unit L1L1 above the pedocomplex L1S1 (No. 11-20, the upper pleniglacial and a part of Late Glacial, MOIS 2). The lithostratigraphic unit L1L1 is very differentiated in the Dankowice profile. There are several initial gley levels, although the horizons 12, 14 and 19 are particularly distinguishable. The upper parts of these levels are usually deformed by periglacial gelifluction. The presence of ice wedge-cast has been noticed just a few meters from the main profile. This is convincing evidence of the presence of permafrost during the period of the last glacial maximum (Jary 2009a, b, 2010).

At the top of loess L1L1 contemporary brown soil S0 (No. 21-23, Fig. 2) with superimposed, thick accumulation horizon was developed.

\section{Geochemical analysis of loess samples and selected chemical weathering indices}

For the investigation of the chemical composition of loess-soil sequence in Dankowice, 31 archival loess samples, collected in 2001 and stored in the geological samples archive of the Department of Physical Geography, University of Wrocław were used.

The selected samples of loess were dried in laboratory dryers at $105^{\circ} \mathrm{C}$ for $24 \mathrm{~h}$. Then the samples weight $(5 \mathrm{~g})$ were burned in the muffle furnace at $1000^{\circ} \mathrm{C}$, for a period of $1 \mathrm{~h}$ to calculate the loss on ignition (LOI). From the burned sample a $250 \mathrm{mg}$ of material was taken and mixed with flux (lithium borate). The mixture was melted in platinum crucible in the flame of a Bunsen burner at approx. $900^{\circ} \mathrm{C}$. The resulting melt was dissolved in $10 \%$ $\mathrm{HCl}$ and diluted with $250 \mathrm{ml}$. Using atomic absorption method, in the obtained solutions the $\mathrm{Na}, \mathrm{K}, \mathrm{Mg}, \mathrm{Ca}, \mathrm{Fe}$, $\mathrm{Mn}, \mathrm{Al}$ and Ti were determined. Phosphorus was measured colorimetrically after mineralization the sample in microwave device. The resulting values of element concentrations were converted to oxides (excluding volatile components). Silica was not measured assuming it is a complement to $100 \%$. This assumption was confirmed by the analysis and comparison of standards, i.e. loess indications certified reference materials ISE 934 and ISE 974 Dutch company Wepal. Analysis of these materials enables validation of the method, ensure the credibility of the analysis and is essential in any modern analytical laboratory (Migaszewski, Gałuszka 2007).

In the contemporary geochemical literature indirect indicators for the assessment of the intensity of chemical weathering of sediments and fossil soils are commonly used. A tremendous amount of various indices is proposed (e.g. Duzgoren-Aydin et al. 2002, Price, Velbel 2003, Bahlburg, Dobrzinski 2011, Buggle et al. 2011). Among them, the authors of this study have chosen six that, in their opinion, are the best for characterizing the intensity of chemical weathering.

CIA - (chemical index of alteration - Nesbitt, Young 1982, 1984, 1989), the coefficient expressed in molar proportions, calculated by the following formula: 


$$
\mathrm{CI} A=\frac{\left(\mathrm{Al}_{2} \mathrm{O}_{3}\right)}{\left(\mathrm{Al}_{2} \mathrm{O}_{3}+\mathrm{CaO} \mathrm{Na}_{2} \mathrm{O}+\mathrm{K}_{2} \mathrm{O}\right)} \times 100 \%
$$

$\mathrm{CaO}^{*}$ - represents $\mathrm{Ca}$ in silicate-bearing minerals only.

The authors had no conditions needed for the separation the silica calcium of carbonate calcium. For this reason, the McLennan procedure (1993) was used, which assumes that the number of $\mathrm{CaO} *$ moles cannot be higher than the number of $\mathrm{Na}_{2} \mathrm{O}$ moles. The $\mathrm{CaO}^{*}$ concentration was calculated based on the following procedure: if the concentration of $\mathrm{CaO}$ was less than or equal to the concentration of $\mathrm{Na}_{2} \mathrm{O}$ in the sample, the $\mathrm{CaO}$ value was adopted; if the $\mathrm{CaO}$ concentrations were higher than the $\mathrm{Na}_{2} \mathrm{O}$ concentrations in the sample, it is assumed that the $\mathrm{CaO}^{*}$ value was equal to the $\mathrm{Na}_{2} \mathrm{O}$ value (Bock et al. 1998, Gallet et al. 1998, Roddaz et al. 2006, Ujvari et al. 2008).

This index assumes that if the intensity of chemical weathering processes increases, the mobile ion content: calcium, sodium and potassium - decreases, and this is manifested by an increase in the value of the CIA. CIA index for kaolinite is approx. 100 and represents the highest degree of weathering, for illite range between 75 and 90 , for muscovite approx. 75 for feldspar about 50. CIA value for fresh basalt ranges 30-45, and for granite and granodiorite 45-55 (Bahlburg, Dobrzinski 2011). CIA values calculated for loess and presented in the literature are in the range of 50 to 75 (e.g. Gallet et al. 1996, 1998, Łącka et al. 2007, Ujvari et al. 2008, Buggle et al. 2011).

CIW - (chemical index of weathering - Harnois 1988), the coefficient expressed in molar proportions, calculated by the following formula:

$$
\mathrm{CIW}=\frac{\left(\mathrm{Al}_{2} \mathrm{O}_{3}\right)}{\left(\mathrm{Al}_{2} \mathrm{O}_{3}+\mathrm{CaO}^{*}+\mathrm{Na}_{2} \mathrm{O}\right)} \times 100 \%
$$

$\mathrm{CaO}^{*}$ - represents $\mathrm{Ca}$ in silicate-bearing minerals only.

CIW index is similar to the previously mentioned CIA ratio. However, it does not take into account potassium, which, as a very mobile element, is quickly removed from the system and is rapidly bonded to soil sorption complex and the living organisms (Düzgören-Aydin et al. 2002, Price, Velbel 2003).

CPA - (chemical proxy of alteration - Buggle et al. 2011; previously proposed by Cullers (2000) as CIW'), the coefficient expressed in molar proportions, calculated by the following formula:

$$
\mathrm{CPA}=\frac{\left(\mathrm{Al}_{2} \mathrm{O}_{3}\right)}{\left(\mathrm{Al}_{2} \mathrm{O}_{3}+\mathrm{Na}_{2} \mathrm{O}\right)} \times 100 \%
$$

This indicator is particularly useful for determining the weathering degree of silicates, aluminosilicates, and plagioclase. It is recommended by Buggle and co-authors
(2011) as the best indicator for the assessment of the degree of weathering of silicates in the loess.

$\mathrm{Al} /$ bases - commonly used index to evaluating the intensity of the hydrolysis process in the soil (Retallack 2001). The coefficient expressed in molar proportions, calculated by the following formula:

$$
A l / \text { bases }=\frac{\left(\mathrm{Al}_{2} \mathrm{O}_{3}\right)}{\left(\mathrm{CaO}+\mathrm{MgO}+\mathrm{K}_{2} \mathrm{O}+\mathrm{Na}_{2} \mathrm{O}\right)}
$$

$\mathrm{Fe}_{2} \mathrm{O}_{3} / \mathrm{TiO}_{2}$ - represents the weight ratio of the medium mobile elements $\left(\mathrm{Fe}_{2} \mathrm{O}_{3}\right)$ to immobile elements $\left(\mathrm{TiO}_{2}\right)$. Especially recommended by Muhs and co-authors (2001a, b), as a good indicator of chemical weathering, and the relative content of clay minerals.

WI - (Weathering Index - Pye, Johnson 1988). The coefficient expressed in weight proportions, calculated by the following formula:

$$
W I=\frac{\left(\mathrm{Al}_{2} \mathrm{O}_{3}+\mathrm{Fe}_{2} \mathrm{O}_{3}\right)}{\left(\mathrm{Na}_{2} \mathrm{O}+\mathrm{K}_{2} \mathrm{O}\right)}
$$

A simple, not-molar index of post-deposition chemical weathering, applied by Pye and Johnson (1988) for loess of Mississippi Valley. It follows from the proportion of low mobile to mobile oxides.

\section{Geochemical composition of loess-soil sequence in Dankowice}

Geochemical composition of loess-soil sequence in Dankowice was determined on the basis of 31 samples.

In the whole profile prevails silica (from 76.62 to $88.76 \%$, mean $80.78 \%$; Fig. 3, Table 1, 2). The highest concentrations of silica is observed in the contemporary soil S0 (average $83.33 \%$ ) and in the group of fossil soils S1 $(83.14 \%$ - Table 2). Proportion of silica in units L1L1 and L1S1 is relatively aligned with the exception for two local minima in the loess L1L1 reported at depths of 200 and $550 \mathrm{~cm}$ (respectively $76.62 \%$ and $76.89 \%$, Table 1, Fig. 3).

The concentrations of aluminum oxide in the Dankowice section varies in the range from 7.24 to $14.34 \%$ (mean $10.56 \%$, Table 1,2). The highest profile concentrations are present in the soil-loess unit L1S1 (mean 11.83\%) and the lowest concentrations of aluminum were found in the level of contemporary soil S0 (average $9.03 \%$ ). The greatest diversity of its content was recorded in the group of fossil soils S1 (from 7.24 to $14.34 \%$, Table 1, 2).

The iron oxide content in the Dankowice profile ranges from 1.31 to $3.1 \%$ (average $2.23 \%$ ). The highest content of this component was found in soil-loess unit L1S1 (average 2.61\%), and lowest in the loess L1L1 (average $2.1 \%$ - Fig. 3, Table 1,2), where the iron concentrations are relatively most aligned in a profile. Greatest variabil- 


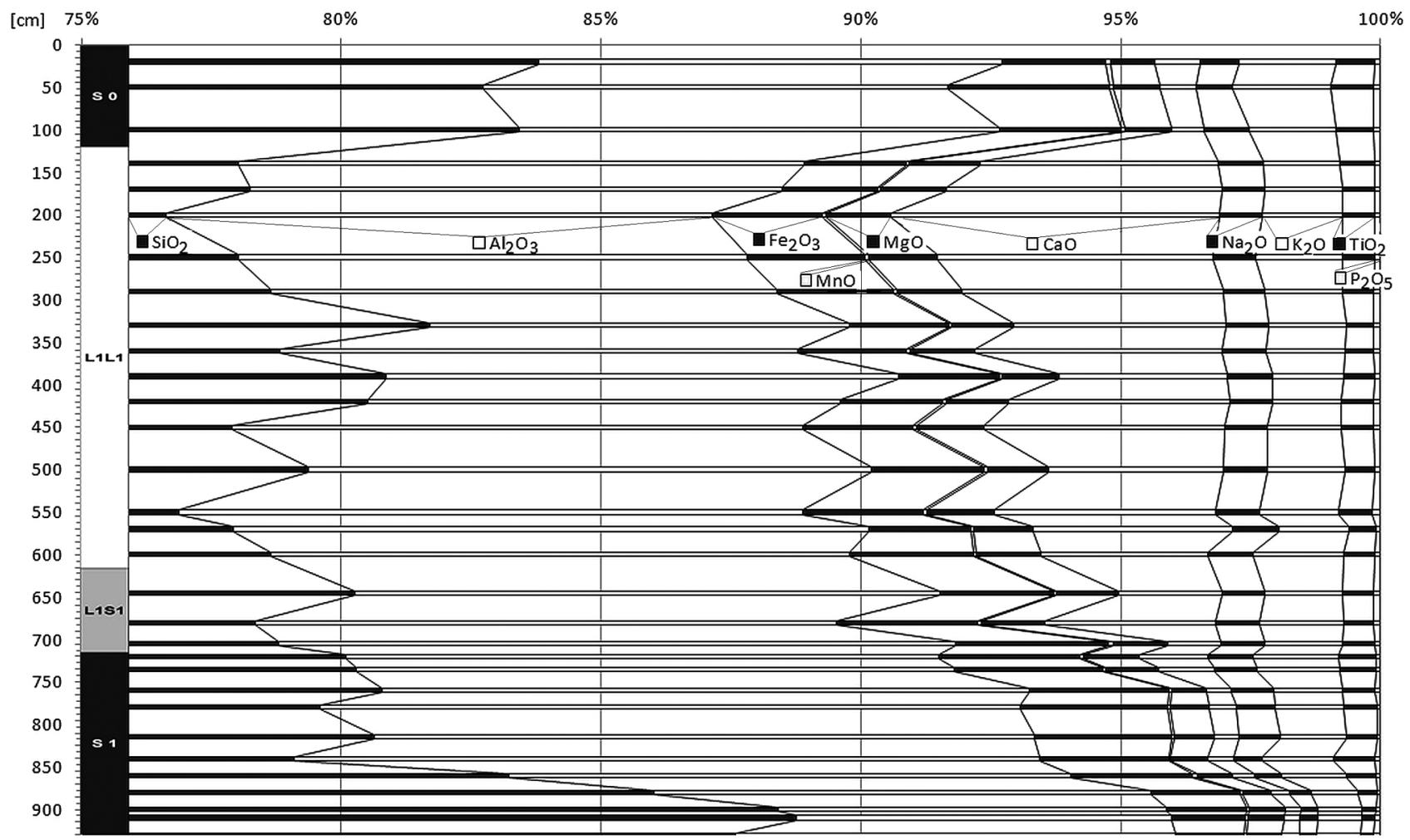

Fig. 3. Chemical composition of the loess-soil sequence in Dankowice (major oxides are in weight percentage, recalculated on a volatile-free basis)

ity of iron concentrations were reported in pedocomplex S1.

The concentrations of potassium oxide in the tested sequence are in the range from 0.84 to $1.89 \%$ (average $1.43 \%$ ). The highest concentrations were in the contemporary soil $\mathrm{S} 0$, and the lowest concentrations of potassium were found in pedocomplex S1 (mean 1.2\%, Fig. 3, Table $1,2)$.

The calcium oxide concentrations in the Dankowice section are very diverse (from 0.3 to $6.34 \%$, on average, $2.48 \%$ ). Low concentrations in soil levels S0 and S1 (respectively 0.72 and $0.55 \%$ ), contrast very high concentrations of calcium in the loess L1L1 (average $4.45 \%$ ). The profile maximum of calcium was found at depth of 200 $\mathrm{cm}(6.34 \%)$ in the upper part of the loess L1L1 (Fig. 3, Table 1, 2).

The content of magnesium oxide is in the range from 0.56 to $1.35 \%$ (average $1.02 \%$ ). The lowest concentrations of magnesium were found in pedocomplex S1 (average $0.76 \%$ ) and the highest in loess L1L1 (average 1.23\%). The profile maximum of magnesium was found at depth of $140 \mathrm{~cm}(1.35 \%)$ in the top part of the loess L1L1 (Fig. 3, Table 1, 2).

The concentration of sodium oxide in the loess-soil sequence in Dankowice profile ranges from 0.31 to $0.9 \%$ (average of 0.74 ). The lowest concentration and also the largest variation of the content of sodium was found in the group of fossil soils S1 (from 0.31 to $0.86 \%$, average $0.59 \%$ - Fig. 3, Table 1, 2).

The titanium distribution in the Dankowice profile ranges from 0.24 to $0.83 \%$ (average $0.59 \%$ ). The highest concentrations of titanium were found in the contemporary soil S0 (average $0.77 \%$ ), and lowest in the group of fossil soils S1 (0.52\%, Fig. 3, Table 1, 2)

The concentration of phosphorus and manganese in the Dankowice profile is the lowest among the analyzed oxides. The phosphorus content is within the range from 0.06 to $0.16 \%$ (average $0.111 \%$ ). The highest of its contents were found in the contemporary soil S0 (average $0.126 \%$ ) and the lowest were recorded in the group of fossil soils S1 $(0.093 \%$, Table 1, 2). The highest average concentrations of manganese were found in the contemporary soil S0 $(0.080 \%)$, and lowest in the group of fossil soils S1 (average $0.056 \%$, Table 1, 2).

LOI ranges from 1.91 to $7.64 \%$ (average $4.68 \%$ ). The highest average value (5.61\%), and the smallest variation in loss on ignition were found in L1S1 (Table 1, 2).

\section{Geochemical characteristics of litho- pedostratigraphic units}

The results of chemostratigraphic research confirm earlier division of litho-pedostratigraphic units of loess-soil sequence in Dankowice (Fig. 3) and complement previously collected archival materials for this section (Ciszek et al. 2001, Jary et al. 2002, 2004a, b, Chlebowski et al. 2004, Fedorowicz et al. 2004, Fedorowicz 2005, 2006, Jary, 2007, 2010).

The contemporary soil S0 in Dankowice is characterized by high homogeneity of the geochemical composition. The lowest values of the coefficients of variation $\mathrm{V}(\%)$ in the profile for the silica, alumina, manganese, 
Table 1. Chemical composition (major oxides are in weight percentage, recalculated on a volatile-free basis) and selected chemical weathering indices of the loess-soil sequence in Dankowice

\begin{tabular}{|c|c|c|c|c|c|c|c|c|c|c|c|c|c|c|c|c|c|c|}
\hline No. & $\begin{array}{c}\text { Depth } \\
{[\mathrm{cm}]}\end{array}$ & $\mathrm{SiO}_{2}$ & $\mathrm{I}_{2} \mathrm{O}_{3}$ & $\mathrm{e}_{2} \mathrm{O}_{3}$ & $\mathrm{MnO}$ & $\mathrm{MgC}$ & $\mathrm{CaO}$ & $\mathrm{Na}_{2} \mathrm{O}$ & $\mathrm{K}_{2} \mathrm{O}$ & $\mathrm{TiO}_{2}$ & $\mathrm{P}_{2} \mathrm{O}_{5}$ & LOI & CIA & CIV & $\mathrm{Cr}_{3}$ & $\begin{array}{c}\mathrm{Al} / \\
\text { bases }\end{array}$ & $\begin{array}{c}\mathrm{Fe}_{2} \mathrm{O}_{3} / \\
\mathrm{TiO}_{2}\end{array}$ & WI \\
\hline 1 & 20 & 83.80 & 8.93 & 1.99 & 087 & 0.85 & .87 & 0.74 & 1.87 & 0.75 & 0.120 & 4.42 & 66.7 & 78.6 & 88.0 & 1.28 & 2.66 & 4.19 \\
\hline 2 & 50 & 82.74 & 8.94 & 3.10 & .077 & 90 & 68 & 0.71 & 1.89 & 0.83 & 132 & 4.14 & 67.2 & 79.3 & & 1.33 & 3.72 & 4.64 \\
\hline 3 & 100 & 83.43 & 9.24 & 2.33 & 077 & 91 & 61 & 87 & 1.68 & 0.72 & 127 & 3.44 & 67.9 & 8.4 & 6.6 & 1.39 & 3.22 & 4.54 \\
\hline 4 & 140 & 78.02 & 10.89 & 1.98 & 0.054 & 1.35 & 4.59 & 0.87 & 1.46 & 0.68 & 0.110 & 3.40 & 71.0 & 79.1 & 88.3 & 0.74 & 2.89 & 5.51 \\
\hline 5 & 170 & 78.26 & 10.22 & 1.84 & 57 & .26 & 1 & 82 & 1.48 & 0.62 & 118 & 3.55 & 70.4 & 79.1 & .3 & 0.65 & 2.95 & 5.24 \\
\hline 6 & 200 & 76.62 & 10.51 & 2.14 & 0.062 & 1.24 & 6.34 & 0.81 & 1.54 & 0.63 & 0.111 & 5.62 & 70.8 & 79.8 & 88.8 & 0.60 & 3.37 & 5.38 \\
\hline 7 & 250 & 78.02 & 9.79 & 2.27 & 067 & 1.33 & J.J1 & 0.82 & 1.67 & 0.60 & 121 & 5.46 & 68.5 & 78.4 & 87.9 & 0.60 & 3.78 & 4.85 \\
\hline 8 & 290 & 78.64 & 9.75 & 2.24 & 0.075 & 1.25 & 5.03 & 0.80 & 1.51 & 0.60 & 0.124 & 5.91 & 69.6 & 78.8 & 88.2 & 0.64 & 3.73 & 5.21 \\
\hline 9 & 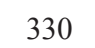 & 81.70 & 09 & 1.91 & 49 & 1.18 & 9 & 0.83 & 1.48 & 0.53 & 134 & 5.23 & 65.2 & 74.8 & 85.6 & 0.60 & 3.61 & 4.33 \\
\hline 10 & 360 & 78.82 & 9.9 & 2.10 & 0.074 & 1.23 & 4.77 & 0.83 & 1.51 & 0.56 & 0.132 & 5.73 & 69.5 & 78.4 & 87.9 & 0.67 & 3.72 & 5.15 \\
\hline 11 & 3 & 80.85 & 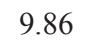 & .95 & 61 & 1.09 & 3.22 & 0.89 & 1.35 & 0.60 & 117 & 6.01 & 69.2 & 77.1 & 87.0 & 0.85 & 3.24 & 5.27 \\
\hline 12 & 42 & 52 & 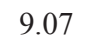 & 1.98 & 061 & 1.21 & & 81 & 1.33 & 0.62 & 39 & & & 3 & .2 & 0.67 & 3.21 & 5.17 \\
\hline 13 & 450 & 77.90 & 10.98 & 2.13 & 0.081 & 1.28 & 4.64 & 0.81 & 1.43 & 0.63 & 0.127 & 5.83 & 72.3 & 80.5 & 89.2 & 0.75 & 3.37 & 5.86 \\
\hline 14 & 50 & 79.37 & & 2.18 & & & & & & & & & 71.1 & .6 & .7 & 0.89 & 3.84 & 5.52 \\
\hline 15 & 550 & 76.89 & 12.00 & 2.32 & 0.075 & 1.27 & 4.26 & 0.85 & 1.54 & 0.64 & 0.156 & 6.51 & 72.9 & 81.1 & 89.6 & 0.86 & 3.62 & 6.00 \\
\hline 16 & 57 & 77.92 & 12.24 & 1.96 & & 1.14 & & & & 0.52 & 0.096 & 4.89 & 73.6 & 80.5 & 89.2 & 0.96 & 3.74 & 6.37 \\
\hline 17 & 600 & 78.65 & 11.13 & 2.38 & 0.065 & 1.24 & 3.21 & 0.85 & 1.75 & 0.62 & 0.101 & 7.64 & 70.3 & 79.9 & 88.8 & 0.91 & 3.87 & 5.20 \\
\hline 18 & 645 & 80.26 & 11.27 & 2.19 & 0.050 & 1.18 & 1.99 & 0.82 & 1.51 & 0.60 & 0.126 & 5.76 & 72.2 & 80.6 & 89.3 & 1.18 & 3.64 & 5.78 \\
\hline 19 & 680 & 78.34 & 11.20 & 2.71 & 0.064 & 1.22 & & 0.85 & 1.61 & 0.59 & 0.127 & & 71.2 & 80.0 & 88.9 & 0.92 & 4.59 & 5.66 \\
\hline 20 & 705 & 78.79 & 13.03 & 2.93 & 0.114 & 1.03 & 1.03 & 0.84 & 1.50 & 0.63 & 0.107 & 5.34 & 74.8 & 82.5 & 90.4 & 1.74 & 4.65 & 6.82 \\
\hline 21 & 720 & 80.09 & 11.41 & 2.71 & 0.071 & 1.05 & 1.33 & 0.86 & 1.65 & 0.73 & 0.090 & 6.62 & 71.2 & 80.1 & 88.9 & 1.38 & 3.74 & 5.63 \\
\hline 22 & 735 & 80.28 & 11.51 & 2.86 & 0.059 & 1.02 & 1.07 & 0.82 & 1.60 & 0.69 & 0.087 & 4.79 & 72.3 & 81.1 & 89.5 & 1.51 & 4.12 & 5.95 \\
\hline 23 & 760 & & & 2.69 & & & & & & 0.62 & & & 77.5 & 84.9 & 90.2 & 2.34 & 4.33 & 7.09 \\
\hline 24 & 780 & 79.59 & 13.47 & 2.85 & 0.036 & 0.77 & 0.51 & 0.76 & 1.33 & 0.63 & 0.068 & 5.25 & 78.9 & 86.1 & 91.5 & 2.43 & 4.49 & 7.83 \\
\hline 25 & 815 & 80.65 & & 2.63 & & 0.76 & & & 1.28 & 0.60 & 0.062 & 3.63 & 78.1 & 85.4 & 90.7 & 2.31 & 4.38 & 7.43 \\
\hline 26 & 840 & 79.10 & 14.34 & 2.48 & 0.033 & 0.73 & 0.49 & 0.56 & 1.36 & 0.81 & 0.104 & 3.17 & 81.4 & 88.9 & 94.0 & 2.80 & 3.07 & 8.77 \\
\hline 27 & 860 & 83.22 & 10.80 & 2.34 & 0.113 & 0.67 & 0.42 & 0.52 & 1.25 & 0.57 & 0.090 & 2.95 & 78.4 & 86.9 & 92.6 & 2.31 & 4.11 & 7.42 \\
\hline 28 & 880 & 85.98 & 9.57 & 1.71 & 0.043 & 0.56 & 0.35 & 0.43 & 0.91 & 0.35 & 0.071 & 2.12 & 80.5 & 87.8 & 93.2 & 2.57 & 4.85 & 8.45 \\
\hline 29 & 900 & 88.40 & 7.48 & 1.54 & 0.048 & 0.71 & 0.30 & 0.31 & 0.87 & 0.25 & 0.096 & 1.91 & 79.3 & 88.0 & 93.6 & 1.98 & 6.07 & 7.66 \\
\hline 30 & 910 & 88.76 & 7.24 & 1.42 & 0.044 & 0.69 & 0.31 & 0.34 & 0.86 & 0.24 & 0.109 & 2.10 & 77.9 & 86.6 & 92.8 & 1.91 & 5.84 & 7.20 \\
\hline 31 & 930 & 87.62 & 8.48 & 1.31 & 0.062 & 0.67 & 0.35 & 0.32 & 0.84 & 0.25 & 0.133 & 1.93 & 81.1 & 88.8 & 94.1 & 2.24 & 5.14 & 8.41 \\
\hline
\end{tabular}

magnesium, calcium and phosphorus were found in this unit (Fig. 4, Table 3). The development of contemporary soil S0 was determined by its location in the area of roadway, while in the peripheral part of the parcel was used as orchard. The profile of soil S0 in Dankowice is not deep, but still the morphological characteristics of individual soil horizons are well developed. Proportion of silica is in the range of 82.74 -aligned to $83.8 \%$ (mean $83,33 \%$, Table 2). The geochemical feature of $\mathrm{S} 0$ units is clear depletion of calcium and magnesium oxides relative to underlaying L1L1 loess unit. Maximum concentrations in the soil profile S0 were found for the silica, manganese, potassium, titanium and phosphorus (Table 1,2)

The concentration of silica in the loess unit L1L1 reaches a minimum at the level of $78.73 \%$ (from 76.62 to $81.7 \%$ ). Loess L1L1 in loess-soil sequence Dankowice is characterized by relatively low coefficients of variation of the analyzed oxides (the lowest values were found for

Table 2. Concentrations of major oxides and LOI (ranges and mean values in \%) for the whole profile and the individual litho-pedostratigraphic units of the Dankowice loess-soil sequence

\begin{tabular}{|c|c|c|c|c|c|c|c|c|c|c|c|c|}
\hline Unit & Depth [m] & $\mathrm{SiO}_{2}$ & $\mathrm{Al}_{2} \mathrm{O}_{3}$ & $\mathrm{Fe}_{2} \mathrm{O}_{3}$ & $\mathrm{MnO}$ & $\mathrm{MgO}$ & $\mathrm{CaO}$ & $\mathrm{Na}_{2} \mathrm{O}$ & $\mathrm{K}_{2} \mathrm{O}$ & $\mathrm{TiO}_{2}$ & $\mathrm{P}_{2} \mathrm{O}_{5}$ & LOI \\
\hline \multirow{2}{*}{ Profile } & \multirow{2}{*}{$0.0-9.3$} & $76.62-88.76$ & $7.24-14.34$ & $1.31-3.1$ & $0.03-0.11$ & $0.56-1.35$ & $0.3-6.34$ & $0.31-0.9$ & $0.84-1.89$ & $0.24-0.83$ & $0.06-0.16$ & $1.91-7.64$ \\
\hline & & 80.78 & 10.56 & 2.23 & 0.064 & 1.02 & 2.48 & 0.74 & 1.43 & 0.59 & 0.111 & 4.68 \\
\hline \multirow{2}{*}{ S0 } & \multirow{2}{*}{$0.0-1.2$} & $82.74-83.8$ & $8.93-9.24$ & $1.99-3.1$ & $0.08-0.09$ & $0.85-0.91$ & $0.61-0.87$ & $0.71-0.87$ & $1.68-1.89$ & $0.72-0.83$ & $0.12-0.13$ & $3.44-4.42$ \\
\hline & & 83.33 & 9.03 & 2.47 & 0.080 & 0.89 & 0.72 & 0.77 & 1.81 & 0.77 & 0.126 & 4.0 \\
\hline \multirow{2}{*}{ L1L1 } & \multirow{2}{*}{$1.2-6.2$} & $76.62-81.7$ & $8.09-12.24$ & $1.84-2.38$ & $0.05-0.08$ & $1.09-1.35$ & $3.21-6.34$ & $0.8-0.9$ & $1.33-1.75$ & $0.52-0.68$ & $0.1-0.16$ & 3.4-7.64 \\
\hline & & 78.73 & 10.38 & 2.10 & 0.064 & 1.23 & 4.45 & 0.84 & 1.49 & 0.6 & 0.121 & 5.52 \\
\hline \multirow{2}{*}{ L1S1 } & \multirow{2}{*}{$6.2-7.2$} & $78.34-80.26$ & $11.2-13.03$ & $2.19-2.93$ & $0.05-0.11$ & $1.03-1.22$ & $1.03-3.3$ & $0.82-0.85$ & $1.5-1.61$ & $0.59-0.63$ & $0.11-0.13$ & $5.34-5.76$ \\
\hline & & 79.13 & 11.83 & 2.61 & 0.076 & 1.14 & 2.1 & 0.84 & 1.54 & 0.61 & 0.120 & 5.61 \\
\hline \multirow{2}{*}{ S1 } & \multirow{2}{*}{$7.2-9.3$} & $79.1-88.76$ & $7.24-14.34$ & $1.31-2.86$ & $0.03-0.11$ & $0.56-1.05$ & $0.3-1.33$ & $0.31-0.86$ & $0.84-1.65$ & $0.24-0.81$ & $0.06-0.13$ & $1.91-6.62$ \\
\hline & & 83.14 & 10.86 & 2.23 & 0.056 & 0.76 & 0.55 & 0.59 & 1.2 & 0.52 & 0.093 & 3.55 \\
\hline
\end{tabular}




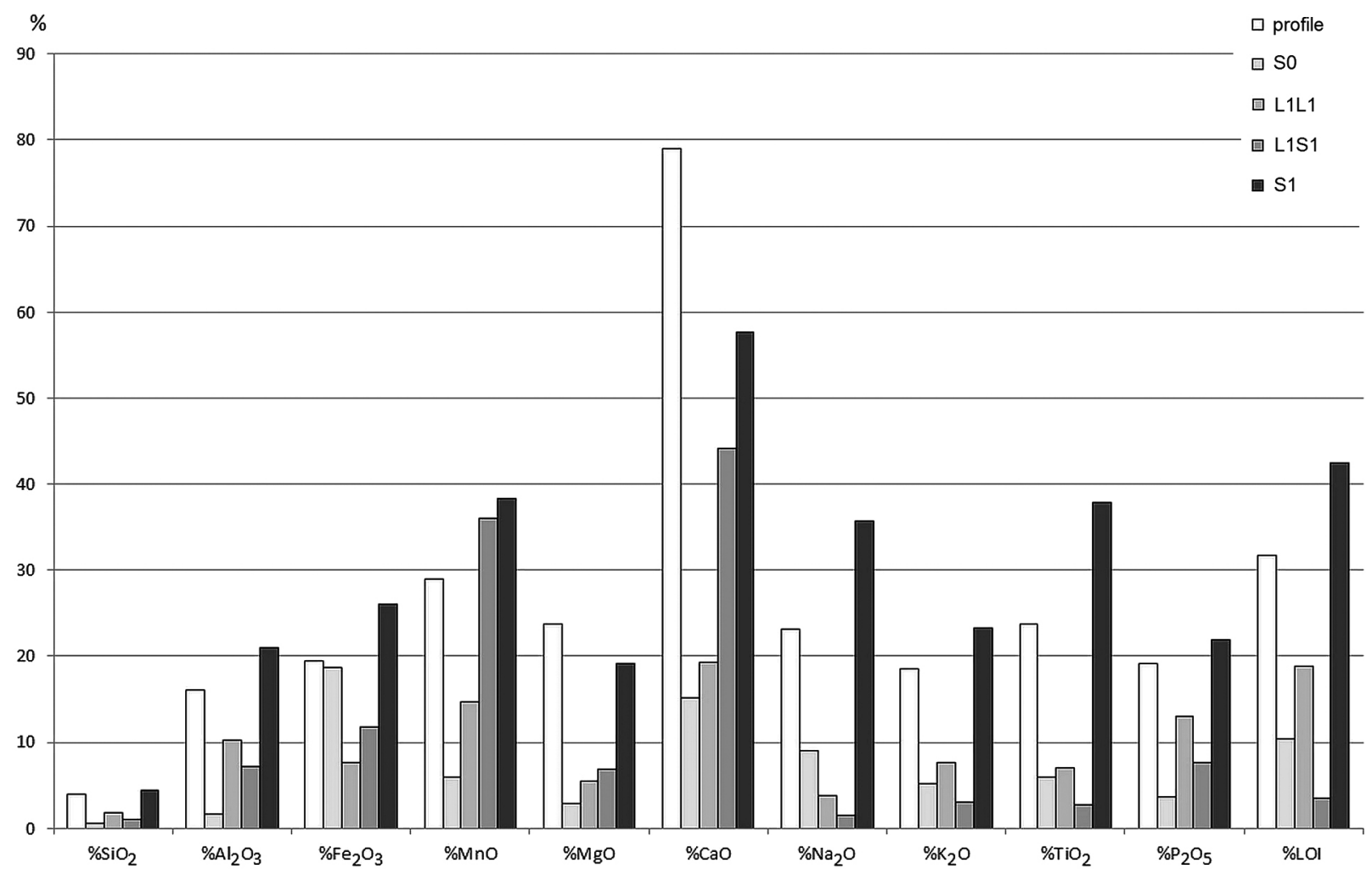

Fig. 4. Coefficients of variation of major oxides and LOI (\%) for the whole profile and the individual litho-pedostratigraphic units of the Dankowice loess-soil sequence

iron), which indicates the high geochemical homogeneity of the loess L1L1 (Fig. 4, Table 3). Clearly increasing concentrations of calcium and magnesium reach the profiles maxima. The results of geochemical analyzes of the samples taken from layer 18 (depth of $200 \mathrm{~cm}$; cf. Figure 3) quite clearly differ from the results obtained for the neighboring samples in particular as regards the concentration of silica and calcium.

A feature of loess-soil unit L1S1 there are the maximum profiles concentrations calculated for the aluminum (average $11.83 \%$ ), and iron (2.61\% on average), and the profiles minima of coefficients of variation (V) identified for the sodium, potassium and titanium, which indicates a relatively high geochemical uniformity of L1S1 loess-soil level (Table 1, 2, 3, Figs 3, 4).

In the fossil soils set $\mathrm{S} 1$, growing proportion of silica, which reaches here a profile point maximum at a depth $910 \mathrm{~cm}$ (Fig. 3, Table 1, 2), and large range of variation of silica is clearly seen (from 79.1 to $88.76 \%$ Figure 4, Table 3). This is accompanied by decreases of the concen- trations of several other oxides. Minima of profiles concentration for manganese, magnesium, calcium, sodium, potassium, titanium and phosphorus were found here. The pedocomplex S1 has the highest coefficients of variation $\mathrm{V}$ for the silica, alumina, iron, manganese, magnesium, calcium, sodium, potassium, titanium and phosphorus (Fig. 4, Table 3).

The largest difference in the distribution of oxides in the profile, measured by the coefficient of variation $\mathrm{V}$ (79.04\%, Table 3) was recorded for calcium oxide, and the lowest for silica $(4.00 \%)$. The units L1L1 and S0 are characterized by greatest uniformity of geochemical composition and the highest geochemical variation was observed for fossil soils set S1 (Fig. 4, Table 3).

\section{The comparison of chemical composition of loess from Dankowice with others loess areas}

The silica content in the tested loess sequence is comparable only with extremely high $\mathrm{SiO}_{2}$ shares quoted in

Table 3. Coefficients of variation of major oxides and LOI (\%) for the whole profile and the individual litho-pedostratigraphic units of the Dankowice loess section

\begin{tabular}{lccrrrrrrrrrr}
\hline \multicolumn{1}{c}{ Unit } & Depth $[\mathrm{m}]$ & $\mathrm{SiO}_{2}$ & $\mathrm{Al}_{2} \mathrm{O}_{3}$ & $\mathrm{Fe}_{2} \mathrm{O}_{3}$ & $\mathrm{MnO}$ & $\mathrm{MgO}$ & $\mathrm{CaO}$ & $\mathrm{Na}_{2} \mathrm{O}$ & $\mathrm{K}_{2} \mathrm{O}$ & $\mathrm{TiO}_{2}$ & $\mathrm{P}_{2} \mathrm{O}_{5}$ & $\mathrm{LOI}$ \\
\hline Profile & $0.0-9.3$ & 4.00 & 16.01 & 19.47 & 29.04 & 23.69 & 79.04 & 23.17 & 18.51 & 23.80 & 17.72 & 31.72 \\
S0 & $0.0-1.2$ & 0.52 & 1.58 & 18.73 & 5.88 & 2.86 & 15.19 & 9.05 & 5.10 & 6.01 & 3.71 & 10.38 \\
L1L1 & $1.2-6.2$ & 1.78 & 10.19 & 7.59 & 14.76 & 5.51 & 19.30 & 3.75 & 7.61 & 7.03 & 12.96 & 18.77 \\
L1S1 & $6.2-7.2$ & 1.04 & 7.14 & 11.81 & 36.01 & 6.82 & 44.21 & 1.43 & 3.10 & 2.67 & 7.70 & 3.44 \\
S1 & $7.2-9.3$ & 4.37 & 21.05 & 26.04 & 38.27 & 19.10 & 57.70 & 35.67 & 23.21 & 37.93 & 21.94 & 42.42 \\
\hline
\end{tabular}


Table 4. Averages of major elements compositions in Dankowice loess section and selected loess areas (major oxides are in weight percentage, recalculated on a volatile-free basis)

\begin{tabular}{|c|c|c|c|c|c|c|c|c|c|c|c|c|}
\hline Locality & $\begin{array}{c}\text { New } \\
\text { Zealand }^{1}\end{array}$ & $\begin{array}{c}\text { Germa- } \\
\text { ny }^{2}\end{array}$ & $\mathrm{USA}^{3}$ & $\begin{array}{l}\text { Sval- } \\
\text { bard }^{4}\end{array}$ & $\begin{array}{l}\text { Argenti- } \\
\text { na }^{5}\end{array}$ & $\begin{array}{c}\text { En- } \\
\text { gland }\end{array}$ & France $^{7}$ & China $^{8}$ & France $^{9}$ & India $^{10}$ & $\begin{array}{c}\text { Hunga- } \\
\text { ry }^{11}\end{array}$ & $\begin{array}{c}\text { Danko- } \\
\text { wice }\end{array}$ \\
\hline No.S. & 5 & 2 & 4 & 6 & 7 & 1 & 7 & 20 & 13 & 17 & 52 & 31 \\
\hline $\mathrm{SiO}_{2}$ & 73.16 & 59.9 & 80.05 & 77.42 & 67.19 & 83.94 & 77.32 & 65.69 & 81.82 & 71.56 & 63.48 & 80.78 \\
\hline $\mathrm{Al}_{2} \mathrm{O}_{3}$ & 15.02 & 7.88 & 10.79 & 11.87 & 15.24 & 8.5 & 8.43 & 13.13 & 9.18 & 12.5 & 13.45 & 10.56 \\
\hline $\mathrm{Fe}_{2} \mathrm{O}_{3}$ & 3.5 & 3.13 & 2.73 & 4.45 & 4.92 & 2.8 & 3.14 & 4.95 & 3.21 & 4.42 & 4.67 & 2.23 \\
\hline $\mathrm{MnO}$ & 0.05 & 0.07 & 0.03 & 0.04 & 0.13 & 0.05 & 0.05 & 0.1 & 0.07 & 0.07 & 0.09 & 0.06 \\
\hline $\mathrm{MgO}$ & 0.99 & 3.91 & 0.92 & 0.84 & 1.53 & 0.59 & 1.08 & 2.36 & 0.69 & 1.9 & 3.62 & 1.02 \\
\hline $\mathrm{CaO}$ & 1.43 & 23.0 & 1.07 & 0.47 & 5.42 & 0.46 & 6.22 & 8.86 & 1.31 & 4.57 & 9.73 & 2.48 \\
\hline $\mathrm{Na}_{2} \mathrm{O}$ & 3.29 & 0.85 & 1.58 & 1.73 & 2.36 & 0.96 & 1.12 & 1.66 & 1.02 & 1.7 & 1.47 & 0.74 \\
\hline $\mathrm{K}_{2} \mathrm{O}$ & 2.37 & 1.3 & 2.47 & 2.43 & 2.31 & 2.05 & 1.81 & 2.51 & 1.99 & 2.44 & 2.37 & 1.43 \\
\hline $\mathrm{TiO}_{2}$ & 0.58 & 0.31 & 0.67 & 0.69 & 0.81 & 0.57 & 0.72 & 0.7 & 0.71 & 0.72 & 0.91 & 0.59 \\
\hline $\mathrm{P}_{2} \mathrm{O}_{5}$ & - & - & - & 0.14 & 0.16 & 0.07 & 0.11 & 0.16 & - & 0.15 & 0.20 & 0.11 \\
\hline
\end{tabular}

${ }^{1}$ Average of 5 loess samples from New Zealand (Taylor et al. 1983).

${ }^{2}$ Average of 2 loess samples from Kaiserstuhl, Germany (Taylor et al. 1983).

${ }^{3}$ Average of 4 loess samples from Kansas and Iowa, USA (Taylor et al. 1983).

${ }^{4}$ Average of 6 loess samples from Spitsbergen (Gallet et al. 1998).

${ }^{5}$ Average of 7 loess samples from Argentina (Gallet et al. 1998).

${ }^{6}$ Loess sample from England (Gallet et al. 1998).

${ }^{7}$ Average of 7 loess samples from Brittany, France (Gallet et al. 1998).

${ }^{8}$ Average of 20 loess samples from China (Taylor et al. 1983, Gallet et al. 1996, Jahn et al. 2001).

${ }^{9}$ Average of 13 loess samples from Normandy, France (Lautridou et al. 1984).

${ }^{10}$ Average of 17 loess samples from Rajasthan, India (Tripathi, Rajamani 1999).

${ }^{11}$ Average of 52 loess samples from South-Baranya, Hungary (Ujvari et al. 2008).

the literature (Table 4). The similar, high concentrations of $\mathrm{SiO}_{2}$ have been found in the central states of the USA (Taylor et al. 1983, Muhs, Bettis III 2000, Muhs et al. 2001a), England (Gallet et al. 1998) and Normandy in France (Lautridou et al. 1984). For comparison, the silica content of loess samples from Kaiserstuhl (SW Germany), south-western Hungary and China Loess Plateau are about 20\% lower (Taylor et al. 1983, Gallet et al. 1996, 1998, Jahn et al. 2001, Ujvari et al. 2008).

High proportions of silica in Dankowice loess are in stark contrast to the low concentrations of most others major oxides. The profile average of $\mathrm{Al}_{2} \mathrm{O}_{3}$ is $10.56 \%$. This value is comparable with those of USA, England and France loess (Table 4), which can be attributed to glacigenic origin. Much higher contents of $\mathrm{Al}_{2} \mathrm{O}_{3}$ (over 13\%) were found in China, Hungary, New Zealand and Argentina loess (Table 4).

The profile average concentration of $\mathrm{Fe}_{2} \mathrm{O}_{3}(2.23 \%)$ is relatively low. This result is comparable to these of the United States and Great Britain loess (Table 4). The profile average content of manganese oxide is insignificant $(0.06 \%)$, but is similar to the values presented in the literature.

The profile average content of $\mathrm{MgO}(1.02 \%)$ is similar to the concentration of this component in the New Zealand, United States, Svalbard and Brittany loess. This value is higher than in the United States $(0.59 \%)$ and Normandy $(0.69 \%)$, but significantly lower than the $\mathrm{MgO}$ contents in Kaiserstuhl (3.91\%), the Chinese loess Plateau $(2.36 \%)$ and Hungary $(3.62 \%$, Table 4$)$.

The average concentration of $\mathrm{CaO}$ in the whole Dankowice profile is $2.48 \%$. The data taken from literature confirm the large variation of this component: from
$0.46 \%$ (England and Svalbard) to $9.73 \%$ (Hungary), and even $23 \%$ (Kaiserstuhl - Table 4).

The profile average concentration of sodium oxide in Dankowice loess sequence is $0.74 \%$. This value is comparable only with the loess from Kaiserstuhl, England and France, and far lower than the $\mathrm{Na}_{2} \mathrm{O}$ content in other areas of loess (Table 4).

The profile average of potassium oxide is $1.43 \%$. Lower $\mathrm{K}_{2} \mathrm{O}$ content was found only in Kaiserstuhl (1.3\%) and the highest shares $(2.51 \%)$ were recorded in the China Loess Plateau (Table 4).

The most stable of the tested oxides is $\mathrm{TiO}_{2}$. The profile average content of this component is $0.59 \%$, which is comparable to the data reported in the literature: $0.31 \%$ (Kaiserstuhl) to $0.91 \%$ (Hungary - Table 4 ).

There are no much information in the literature concerning the shares of phosphorus in the loess sequences. The profile average concentration of $\mathrm{P}_{2} \mathrm{O}_{5}$ in Dankowice section is $0.11 \%$. Similar amounts of $\mathrm{P}_{2} \mathrm{O}_{5}$ have been noticed in England (0.07\%) and Brittany $(0.11 \%)$ loess and the highest was determined in the Hungarian loess $(0.20 \%$ - Table 4).

\section{The diversity of chemical weathering indices}

The course of curves illustrating the selected chemical weathering indicators in loess-soil sequence in Dankowice (Fig. 5, Table 5), shows a similar trend, and confirms the earlier division of lito-pedostratigraphic units.

Due to the wide use, and thus the possibility of references to literature, the focus was mainly on the rate of chemical transformations (chemical index of alteration) CIA (Nesbitt, Young 1982, 1984, 1989). CIA takes values 


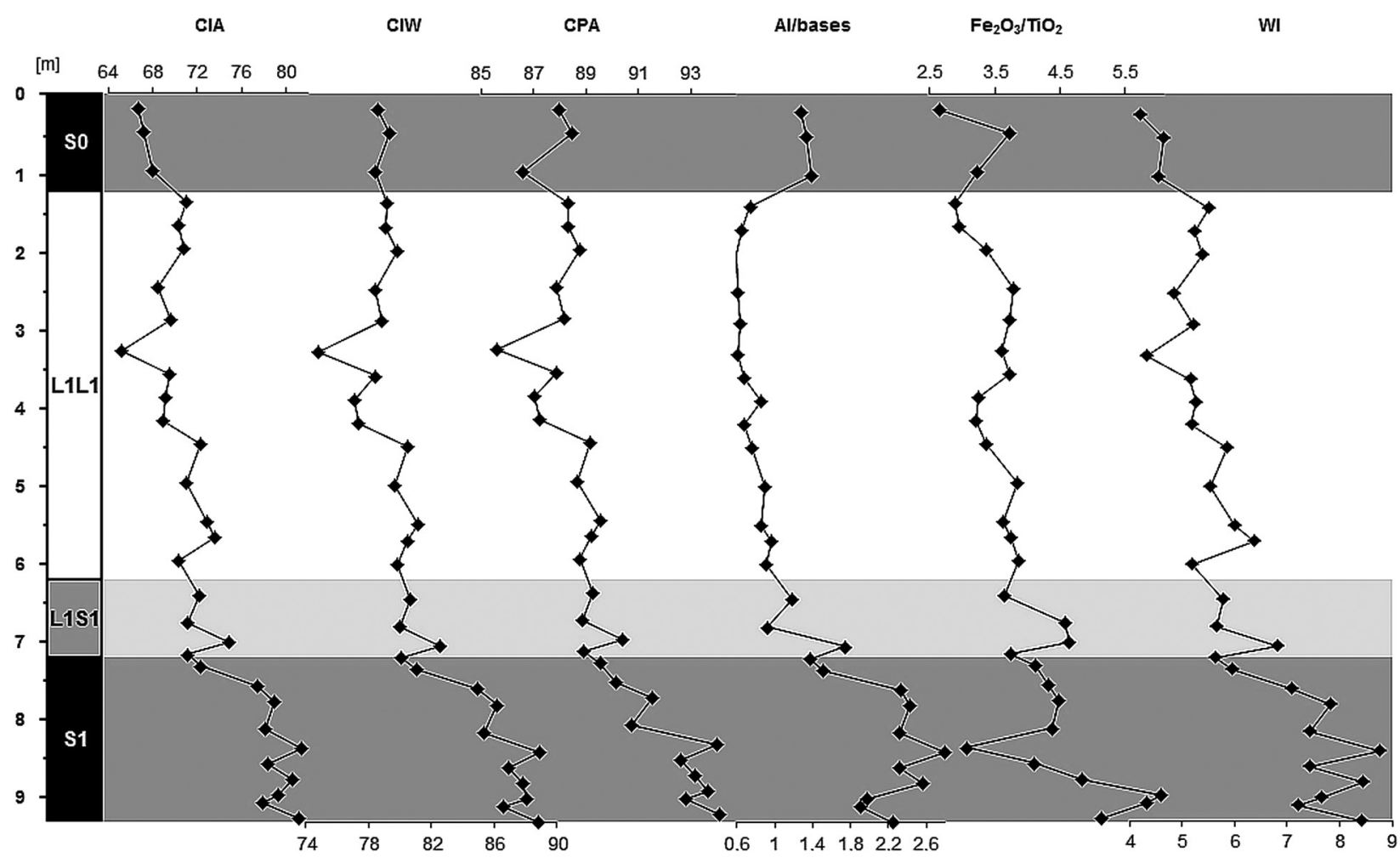

Fig. 5. The variation of selected chemical weathering indices in the Dankowice loess-soil sequence

in the range of 65.2 to 81.4 , indicating a medium and high degree of chemical transformations in the source areas of silt, which have undergone at least one cycle of sedimentation (McLennan 1993, Gallet et al. 1998).

CIA values, presented in this study, are comparable, although usually slightly higher, than the CIA values published in the literature (e.g. Gallet et al. 1998, Tripathi, Rajam 1999, Ujvari et al. 2008, Buggle et al. 2011).

The average value of the CIA index in Dankowice profile is 72.9. The highest differing values of the CIA were stated in the pedocomplex S1, and lowest in the contemporary soil S0. High diversity of the CIA index in pedocomplex $\mathrm{S} 1$ is probably related to the lithological and genetic variation of parent material of this unit. Similarly, large differences in the loess L1L1 may confirm the hypothesis about the significant role of local sources of silt for loess of south-western Poland (e.g. Raczkowski 1969, 1976, Cegła 1984, Jary, Kida 2000).
The curves of the CIA and other indicators of the chemical weathering intensity of loess-soil sequence in Dankowice clearly show the downward trend towards the top of profile (Fig. 5, Table 5). This direction of the CIA curve relates generally to entire profile, but it is also very well recorded in particular litho-pedostratigraphic units, especially in the loess unit L1L1. This may mean that the source areas of loess silt were subjected to significant evolution during the last glaciation, providing with time less and less modified by prolonged and intense chemical weathering processes material.

High variability of chemical weathering indices can also be achieved with the assumption that the accumulation of loess covers was made partly by deposition of silt resulting from the destruction of local silty cover and soils, which were characterized by high rates of chemical weathering. The share of such material could be significant in the early stage of loess-forming phases, in periods

Table 5. Chemical weathering indices (ranges and mean values in \%) for the whole profile and the individual litho-pedostratigraphic units of the Dankowice loess section

\begin{tabular}{|c|c|c|c|c|c|c|c|}
\hline Unit & $\operatorname{Depth}[\mathrm{m}]$ & CIA & CIW & CPA & Al/bases & $\mathrm{Fe}_{2} \mathrm{O}_{3} / \mathrm{TiO}_{2}$ & WI \\
\hline \multirow{2}{*}{ Profile } & \multirow{2}{*}{$0.0-9.3$} & $65.2-81.4$ & $74.8-88.9$ & $85.6-94.1$ & $0.6-2.8$ & $2.66-6.07$ & $4.19-8.77$ \\
\hline & & 72.9 & 81.6 & 89.6 & 1.36 & 3.92 & 6.08 \\
\hline \multirow{2}{*}{ S0 } & \multirow{2}{*}{$0.0-1.2$} & $66.7-67.9$ & $78.4-79.3$ & $86.6-88.5$ & $1.28-1.39$ & $2.66-3.72$ & $4.19-4.64$ \\
\hline & & 67.3 & 78.8 & 87.7 & 1.33 & 3.20 & 4.46 \\
\hline \multirow{2}{*}{ L1L1 } & \multirow{2}{*}{$1.2-6.2$} & $65.2-73.6$ & $74.8-81.1$ & $85.6-89.6$ & $0.6-0.96$ & $2.89-3.87$ & $4.33-6.37$ \\
\hline & & 70.2 & 78.9 & 88.2 & 0.74 & 3.5 & 5.36 \\
\hline \multirow{2}{*}{ L1S1 } & \multirow{2}{*}{$6.2-7.2$} & $71.2-74.8$ & $80-82.5$ & $88.9-90.4$ & $0.92-1.74$ & $3.64-4.65$ & $5.66-6.82$ \\
\hline & & 72.7 & 81.0 & 89.5 & 1.28 & 4.29 & 6.09 \\
\hline \multirow{2}{*}{$\mathrm{S} 1$} & \multirow{2}{*}{$7.2-9.3$} & $71.2-81.4$ & $80.1-88.9$ & $88.9-94.1$ & $1.38-2.8$ & $3.07-6.07$ & $5.63-8.77$ \\
\hline & & 77.9 & 85.9 & 91.9 & 2.16 & 4.56 & 7.44 \\
\hline
\end{tabular}


of sudden deterioration of climatic conditions, leading to the destruction of local vegetation cover.

This interpretation refers to the Van Loon's (2006) considerations about the possibility of multiple recovery ("recycling") of older loess covers and turning it in the process of formation of the younger loess.

\section{Summary}

The study of the chemical composition of loess-soil sequence in Dankowice (Niemcza-Strzelin Hills) allow to propose several preliminary conclusions.

The method used for determinations of elemental composition, preceded by a rigorous sample preparation procedure, gives correct, reproducible results comparable to the certified reference materials. However, the method requires the continuous validation.

The results of the study of chemical composition of loess-soil sequence in Dankowice are differentiated within the vertical sequence and confirm previous division of litho-pedostratigraphic units. Therefore, the chemostratigraphic method can be successfully used as a one of lithostratigraphic methods. This can be a reliable tool for the development and verification of litho-pedostratigraphic subdivisions in loess-soil sequences.

The chemical composition of loess from Dankowice is not substantially different from the others results presented in the world loess literature. The characteristic feature of Dankowice loess is the high concentration of silica and reduced content of iron, sodium and potassium.

CIA index for this loess takes values in the range of 65.2 to 81.4 . This indicates the medium and high degree of chemical transformations in the source areas of silt which passed at least one sedimentation cycle. These values are comparable, but usually a little higher than the CIA values calculated for the loess from other areas, published in the literature.

Decreasing values of the CIA index to the top of the section may indicate that the source areas of loess silt have undergone significant evolution during the last glaciation, providing material over time, less and less transformed by prolonged and intense chemical weathering processes.

The relatively large variation of chemical weathering indices in Dankowice loess section suggests that the accumulation of loess covers also took place through redeposition of silt recovered from the destroying of local silty cover and soils, characterized by high rates of chemical weathering. This may confirm the hypothesis of multiple recovery ("recycling") of older loess cover and turn it in the process of formation of the younger loess.

\section{References}

Ahmad I., Chandra R., 2013. Geochemistry of loess-paleosol sediments of Kashmir Valley, India: Provenance and weathering. Journal of Asian Earth Sciences 66: 73-89.
Anzel M., 1974. Utwory pyłowe wschodniej części Wzgórz Niemczańskich. Archiwum Instytutu Geografii i Rozwoju Regionalnego Uniwersytetu Wrocławskiego, maszynopis pracy magisterskiej: 41pp.

Bahlburg H., Dobrzinski N., 2011. A review of the chemical index of Alteration (CIA) and its application to the study of Neoproterozoic glacial deposits and climate transitions. In: Arnaud E., Halverson G.P., Shields, G.A. (eds.). The Geological Record of Neoproterozoic Glaciations. Memoir, 36. Geological Society. London: 81-92.

Bock B., McLennan S.M., Hanson G.N., 1998. Geochemistry and provenance of the Middle Ordovician Austin Glen Member (Normanskill Formation) and the Taconian Orogeny in New England. Sedimentology 45: 635-655.

Buggle B., Glaser B., Hambach U., Gerasimenko N., Marković S.B., 2011. An evaluation of geochemical weathering indices in loess-paleosol studies. Quaternary International 240: 12-21.

Buggle B., Glaser B., Zoller L., Hambach U., Marković S., Glaser I., Gerasimenko N., 2008. Geochemical characterization and origin of Southeastern and Eastern European loesses (Serbia, Romania, Ukraine). Quaternary Science Reviews 27: 1058-1075.

Cegła J., 1984. Stan badań formacji lessowej Polski SW. W: Seminarium Lessowe „Płaskowyż Głubczycki” (25-27 czerwiec 1984), Instytut Geograficzny Uniwersytetu Wrocławskiego: 1-5.

Chlebowski R., Ciszek D., Jary Z., Kida J., 2004. Charakterystyka mineralogiczna lessów z wybranych profilów przedpola Sudetów w oparciu o analizę minerałów ciężkich. W: Jary, Z., (red.), Zmiany klimatu zapisane w sekwencjach lessowych. IV Seminarium Lessowe. Strzelin 13-16 października 2004. Instytut Geografii i Rozwoju Regionalnego Uniwersytetu Wrocławskiego: 22-27.

Ciszek D., 1997. Uwagi o sedymentacji lessów na Wzgórzach Niemczańskich i w Kotlinie Kłodzkiej. In: Krzyszkowski, D. \& Przybylski, B. (eds.), Problemy zlodowaceń środkowopolskich w Polsce południowo-zachodniej, Przewodnik IV Konferencji Stratygrafia Plejstocenu Polski, Wrocław: 161-162.

Ciszek D., Jary Z., Kida J., Karamański P., 2001. Profil lessowy w Dankowicach (Wzgórza Niemczańsko-Strzelińskie). W: Jary Z., Kida J., (red.), Osady plejstoceńskie przedpola Sudetów. XI Seminarium „Korelacja stratygraficzna lessów i utworów lodowcowych Polski i Ukrainy”, Wrocław-Jarnołtówek 23-28.IX.2001, Instytut Geograficzny Uniw. Wrocł.: 54-57.

Cullers R.L., 2000. The geochemistry of shales, siltstones and sandstones of Pennsylvanian-Permian age, Colorado, USA: implications for provenance and metamorphic studies. Lithos 51: 181-203.

Dodonov A.E., 2007. Loess records - Central Asia. In: Elias, S. (ed.), The Encyclopedia of Quaternary Sciences. Elsevier, Amsterdam: 1418-1429.

Duzgoren-Aydin N.S. Aydin A., Malpas J., 2002. Re-assessment of chemical weathering indices: case study on pyroclastic rocks of Hong Kong. Engineering geology 63: 99-119.

Dwucet K., 1999. Litogeneza górnego lessu vistuliańskiego na Wyżynach Polskich i na Nizinie Śląskiej (Lithogenesis of Vistulian Upper loess in Poland Uplands and Silesian Lowlands). Prace Naukowe Uniwersytetu Śląskiego w Katowicach 1792: 163 pp.

Dwucet K., Śnieszko Z., 1996. Neopleistocene loess cover evolution: an example from the Odonów sedimentary succession (Southern Poland). Biuletyn Peryglacjalny 35: 7-43.

Fedorowicz S., 2005. Korelacja dat TL i OSL próbek z czterech profili lessowych Polski SE i SW. Przegląd Geologiczny 53/11: 1047-1050.

Fedorowicz S., 2006. Metodyczne aspekty luminescencyjnego oznaczania wieku osadów neoplejstoceńskich Europy Środkowej. Wyd. Uniwersytetu Gdańskiego, Gdańsk: 156 pp.

Fedorowicz S., Ciszek D., Jary Z., 2004. Wiek TL próbek z profili lessowych: Biały Kościół, Dankowice, Księginice Małe i Zaprężyn. W: Jary, Z., (red.), Zmiany klimatu zapisane w sekwencjach lessowych. IV Seminarium Lessowe, Strzelin, 13-16 października 2004, Instytut Geografii i Rozwoju Regionalnego Uniwersytetu Wrocławskiego: 33-36.

Gallet S., Jahn B.M., Torii M., 1996. Geochemical characterization of the Luochuan loess-paleosol sequence, China, and paleoclimatic implications. Chemical Geology 133, 67-88.

Gallet S., Jahn B.M., Van Vliet-Lanoë B., Dia A., Rossello E., 1998. Loess geochemistry and its implications for particle origin and composition of the upper continental crust. Earth and Planetary Science Letters 156: 157-172. 
Haase D., Fink J., Haase G., Ruske R., Pécsi M., Richter H., Altermann M., Jäger K.-D., 2007. Loess in Europe - its spatial distribution based on a European Loess Map, scale 1:2,500,000. Quaternary Science Reviews 26: 1301-1312.

Harnois L., 1988. The CIW index: a new chemical index of weathering. Sedimentary Geology 55: 319-322.

Jahn B.M., Gallet S., Han J., 2001. Geochemistry of the Xining, Xifeng and Jixian sections, Loess Plateau of China: eolian dust provenance and paleosol evolution during the last $140 \mathrm{ka}$. Chemical Geology 178: 71-94.

Jary Z., 2007. Zapis zmian klimatu w górnoplejstoceńskich sekwencjach lessowo-glebowych w Polsce i w zachodniej części Ukrainy. Rozprawy Naukowe Instytutu Geografii i Rozwoju Regionalnego Uniwersytetu Wrocławskiego 1, Wrocław: 136 pp.

Jary Z., 2009a. Periglacial markers within the Late Pleistocene loess-palaeosol sequences in Poland and western part of Ukraine. Quaternary International 198: 124-135.

Jary Z., 2009b. Pseudomorfozy klinów lodowych w późnoplejstoceńskich sekwencjach lessowo-glebowych w Polsce i w zachodniej części Ukrainy. [w:] A. Kostrzewski, R. Paluszkiewicz (red.), Geneza, litologia i stratygrafia utworów czwartorzędowych, t. V, Seria Geografia nr 88: $123-138$.

Jary Z., 2010. Loess-soil sequences as a source of climatic proxies: an example from SW Poland. Geologija 52, 1-4 (69-72): 40-45.

Jary Z., Ciszek D., 2013. Late Pleistocene loess-palaeosol sequences in Poland and western Ukraine. Quaternary International 296: 37-50.

Jary Z., Ciszek D., Kida J., 2004a. Profil lessów w Dankowicach koło Strzelina. W: Jary Z., (red.), Zmiany klimatu zapisane w sekwencjach lessowych. IV Seminarium Lessowe, Strzelin 13-16 października 2004, Instytut Geografii i Rozwoju Regionalnego Uniwersytetu Wrocławskiego: 102-107.

Jary Z., Ciszek D., Kida J., 2004b. Zmiany klimatu zapisane w uziarnieniu lessów Przedgórza Sudeckiego. W: Kostrzewski, A., (red.), Geneza, litologia i stratygrafia utworów czwartorzędowych. t. IV, Wydawnictwo Naukowe UAM, Poznań. 137-157.

Jary Z., Kida J., 2000. Loess particles sources, transport and deposition on the example of SW Poland. Acta Universitatis Wratislaviensis 2269, Studia Geograficzne 74: 71-77.

Jary Z., Kida J., Śnihur M., 2002. Lessy i osady lessopochodne w poludniowo-zachodniej Polsce (Loess and loess-derived sediments in SW Poland). Czasopismo Geograficzne 73 (1-2): 63-100.

Jersak J., 1973. Litologia i stratygrafia lessu wyżyn południowej Polski (Lithology and stratigraphy of the loess on the Southern Polish Uplands). Acta Geographica Lodziensia 32: $139 \mathrm{pp}$.

Jersak J., 1985. Poland's loess formations and their facial differentiation. Materials on the Issue of Poland's Loesses, Silesian University, Katowice: $1-9$

Jersak J., 1991. Lessy formacji umiarkowanie wilgotnej na Płaskowyżu Głubczyckim. W: Jersak J. (red.), Less i osady dolinne, Prace Naukowe Uniwersytetu Sląskiego w Katowicach, 1107: 10-49.

Kukla G.J., 1970. Correlation between loesses and deep-sea sediments. Geologiske Foreningen Foerhandlingar 92: 148-180.

Kukla G.J., 1987. Loess stratigraphy in central China. Quaternary Science Reviews 6: 191-219.

Kukla G.J., An Z.S., 1989. Loess stratigraphy in central China. Palaeogeography, Palaeoclimatology, Palaeoecology 72: 203-225.

Łącka B., Łanczont M., Madeyska T., Boguckyj A., 2007. Geochemical composition of Vistulian loess and micromorphology of interstadial palaeosols at the Kolodiiv site (East Carpathian Foreland, Ukraine). Geol. Quart., 51 (2): 127-146.

Lautridou J.P., Sommé J., Jamagne M., 1984. Sedimentological, mineralogical and geochemical characteristics of the loesses of North-West France. In: Pécsi, M. (ed.), Lithology and Stratigraphy of Loess and Paleosols. Geographical Research Institute of the Hungarian Academy of Sciences, Budapest: 121-132.

Markovic S.B., Bokhorst M.P., Vandenberghe J., McCoy W.D., Oches E.A., Hambach U., 2008. Late Pleistocene loess-paleosol sequences in the Vojvodina region, north Serbia. Journal of Quaternary Science, 23: $73-84$.

Martinson D.G., Pisias N.G., Hays J.D., Imbrie J., Moore T.C.Jr., Shackleton N.J., 1987. Age Dating and the Orbital Theory of the Ice Ages:
Development of a High-Resolution 0 to 300,000-Year Chronostratigraphy. Quaternary Research 27; 1-29.

Maruszczak H., 1976. Stratygrafia lessów Polski południowo-wschodniej. Biuletyn Instytutu Geologicznego, 297: 135-175.

Maruszczak H., 1991. Zróżnicowanie stratygraficzne lessów polskich. W: Podstawowe profile lessów w Polsce, H. Maruszczak (ed.), UMCS Lublin, A: 13-35.

McLennan S.M., 1993. Weathering and global denudation. Journal of Geology 101: 295-303.

Migaszewski Z., Gałuszka A., 2007. Podstawy geochemii środowiska. Wydawnictwa Naukowo-Techniczne, Warszawa.

Muhs D.R., 2007. Loess deposits, origins, and properties. In: Elias, S. (ed.), The Encyclopedia of Quaternary Sciences. Elsevier, Amsterdam: pp. 1405-1418.

Muhs D.R., 2013. The geologic records of dust in the Quaternary. Aeolian Research 9: 3-48.

Muhs D.R., Ager T.A., Beget J.E., 2001a. Vegetation and paleoclimate of the last interglacial period, central Alaska. Quaternary Science Reviews 20: 41-61.

Muhs D.R., Ager T.A., Bettis III E.A., McGeehin J., Been J.M., Beget J.E., Pavich M.J., Stafford Jr., T.W., Stevens D.S.P., 2003. Stratigraphy and palaeoclimatic significance of Late Quaternary loess-palaeosol sequences of the Last Interglacial-Glacial cycle in central Alaska. Quaternary Science Reviews 22: 1947-1986.

Muhs D.R., Ager T.A., Skipp G., Beann J., Budahn J., McGeehin J.P., 2008. Paleoclimatic significance of chemical weathering in loess-derived paleosols of Subarctic Central Alaska. Arctic, Antarctic and Alpine Research 40: 396-411.

Muhs D.R., Bettis III E.A., Been, J., McGeehin J.P., 2001b. Impact of climate and parent material on chemical weathering in loess-derived soils of the Mississippi river valley. Soil Science Society of America Journal 65: 1761-1777.

Muhs D.R., Bettis III, E.A., 2000. Geochemical variations in Peoria Loess of western Iowa indicate paleowinds of midcontinental North America during last glaciation. Quaternary Research 53: 49-61.

Muhs D.R., Bettis III, E.A., 2003. Quaternary loess-paleosol sequences as examples of climate-driven sedimentary extremes. Geological Society of America Special Paper 370: 53-74.

Nesbitt H.W., Young G.M., 1982. Early Proterozoic climates and plate motions inferred from major element chemistry of lutites. Nature 299: 715-717.

Nesbitt H.W., Young G.M., 1984. Prediction of some weathering trends of plutonic and volcanic rocks based on thermodynamic and kinetic considerations. Geochimica et Cosmochimica Acta 48: 1523-1534.

Nesbitt H.W., Young G.M., 1989. Formation and diagenesis of weathering profiles. Journal of Geology 97: 129-147.

Porter S.C., 2007. Loess records - China. W: Elias, S. (ed.), The Encyclopedia of Quaternary Sciences. Elsevier, Amsterdam: 1429-1440.

Price J.R., Velbel M.A., 2003. Chemical weathering indices applied to weathering profiles developed on heterogeneous felsic metamorphic parent rocks. Chemical Geology 202: 397-416.

Pye K., Johnson R., 1988. Stratigraphy, geochemistry, and thermoluminescence ages of Lower Mississippi Valley loess. Earth Surface Processes and Landforms 13: 103-124.

Pye K., Sherwin D., 1999. Loess. W: A.S. Goudie, I. Livingstone, S. Stokes (ed.), Aeolian environments, sediments and landforms. John Wiley \& Sons: 213-238.

Raczkowski W., 1960. Less w okolicach Henrykowa na Dolnym Śląsku. Biuletyn Peryglacjalny 7: 95-111.

Raczkowski W., 1969. Lessy i utwory pylaste Przedgórza Sudeckiego. Archiwum Instytutu Geografii i Rozwoju Regionalnego Uniwersytetu Wrocławskiego, maszynopis pracy doktorskiej: 149 pp.

Raczkowski W., 1976. Niektóre problemy genezy lessów Przedgórza Sudeckiego (Some problems of the origin of the Sudetic Foreland Loesses). Biuletyn Instytutu Geologicznego 297: 329-343.

Retallack G., 2001. Soils in the Past. An Introduction to Paleopedology (second edition). Blackwell Science.

Roberts H.M., Muhs D.R., Bettis III E.A., 2007. Loess records - North America. In: Elias, S. (ed.), The Encyclopedia of Quaternary Sciences. Elsevier, Amsterdam: 1456-1466.

Roddaz M., Viers J., Brusset S., Baby P., Boucayrand, C., Hérail, G., 2006. Controls on weathering and provenance in the Amazonian fore- 
land basin: insights from major and trace element geochemistry of Neogene Amazonian sediments. Chemical Geology 226: 31-65.

Rousseau D.D., Derbyshire E., Antoine P., Hatte, 2007. Loess records Europe. In: Elias, S. (ed.), The Encyclopedia of Quaternary Sciences. Elsevier, Amsterdam: 1440-1456.

Różycki S.Z., 1986. Pyłowe utwory typu lessowego na świecie, ich występowanie i geneza. Studia Geologica Polonica, vol. LXXXV: $193 \mathrm{pp}$.

Sun J.M., 2002a. Provenance of loess material and formation of loess deposits on the Chinese Loess Plateau. Earth and Planetary Science Letters 203: 845-859.

Sun J.M., 2002b. Source Regions and Formation of the Loess Sediments on the High Mountain Regions of Northwestern China. Quaternary Research 58: 341-351.

Taylor S.R., McLennan S.M., McCulloch M.T., 1983. Geochemistry of loess, continental crustal composition and crustal model ages. Geochimica et Cosmochimica Acta 47: 1897-1905.

Tripathi J.K., Rajamani V., 1999. Geochemistry of the loessic sediments on Delhi ridge, eastern Thar desert, Rajasthan: implications for exogenic processes. Chemical Geology 155: 265-278.
Újvári G., Varga A., Balogh-Brunstad, Z., 2008. Origin, weathering, and geochemical composition of loess in southwestern Hungary. Quaternary Research 69: 421-437.

Van Loon A.J., 2006. Lost loesses. Earth-Science Reviews 74: 309-316. Wójcik L., 1963. Szczegółowa Mapa Geologiczna Sudetów w skali 1;25 000, Arkusz Kuropatnik (M33-47Cc)., Inst. Geol. Warszawa.

Wójcik L., 1968. Objaśnienia do Szczegółowej Mapy Geologicznej Sudetów w skali 1;25 000, Arkusz Kuropatnik (M33-47Cc). Inst. Geol. Warszawa, Wyd. Geologiczne.

Yang S., Ding F., Ding Z., 2006. Pleistocene chemical weathering history of Asian arid and semi-arid regions recorded in loess deposits of China and Tajikistan. Geochimica et Cosmochimica Acta 70: 1695-1709.

Yang S.Y., Li C.X., Yang D.Y., Li X.S., 2004. Chemical weathering of the loess deposits in the lower Changjiang Valley, China, and paleoclimatic implications. Quaternary International 117: 27-34.

Zarate M.A., 2007. Loess records - South America. In: Elias S. (ed.), The Encyclopedia of Quaternary Sciences. Elsevier, Amsterdam: 1466-1479. 